\title{
Morphology of integuments of the Precambrian animals, Proarticulata
}

\author{
A.Yu. Ivantsov ${ }^{1}$, M.A. Zakrevskaya ${ }^{1}$, A.L. Nagovitsyn ${ }^{2}$ \\ ${ }^{1}$ Borissiak Paleontological Institute, Russian Academy of Sciences, Profsouznaya st. 123, Moscow, \\ 117997, Russia.E-mail: ivancov@paleo.ru \\ 2 Arkhangelsk Regional Museum, Nab. Severnoy Dviny, 85/86, Arkhangelsk, 163000, Russia. \\ E-mail: alnagov@gmail.com
}

ABSTRACT: Proarticulata, the largest mobile animals of the Late Precambrian, inhabited shallow marine basins of normal salinity in Baltica (eastern and northern Europe) and East Gondwana (Australia) in the Late Ediacaran. They represented a substantial part of benthic palaeocommunities of macroorganisms inhabiting microbial mats, and at least some of them fed on the upper lamina of such a mat, absorbing the nutrition by their ventral side. Moulds attributed to the Proarticulata were formed by sub-bilateral organisms, divided into two transverse rows of half-segments (isomers). It was established that these moulds did not represent the entire body, but only a part, that was relatively resistant to decomposition. This sack-like structure, divided into transverse elements, enveloped the dorsal and ventral sides of the body but did not spread to its inner parts. It was dense and probably served as a resilient support. On the dorsal side, this integument created a continuous shield that showed no signs of segmentation. The outer surface of the dorsal side of several genera of the Proarticulata was covered with numerous evenly distributed tubercles. In a single specimen, the tissue at the posterior end of the body formed a pair of long filamentous outgrowths. Based on the feeding traces, it was inferred that the ventral side of the body was segmented externally similar to the supporting structure. The cover tissue on the ventral side probably bore cilia and furrows of suggested ciliary sweeping were preserved on the traces. The integument and segmented structure are interpreted as an epidermal tissue and a basal matrix underlying it. A tissue organization in combination with the anteroposterior and dorsoventral polarity of the Proarticulata body allow us to assign them to the Eumetazoa and Bilateria.

How to cite this article: Ivantsov Yu.A., Zakrevskaya M.A., Nagovitsyn A.L. 2019. Morphology of integuments of the Precambrian animals, Proarticulata // Invert.Zool. Vol.16. No.1. P. 19-26. doi: 10.15298/invertzool. 16.1.03

KEY WORDS: Dickinsonia, Yorgia, Proarticulata, Bilateria, Eumetazoa, Late Precambrian, Ediacaran.

\section{Морфология покровов докембрийских животных проартикулят}

\author{
А.Ю. Иванцов ${ }^{1}$, М.А. Закревская ${ }^{1}$, А.Л. Наговицын ${ }^{2}$ \\ ${ }^{1}$ Палеонтологический институт им. А.А. Борисяка РАН, ул. Профсоюзная, 123, Москва, \\ 117647, Росcuя.E-mail: ivancov@paleo.ru \\ 2 Архангельский краеведческий музей, наб. Северной Двины, 85/86, Архангельск, 163000, \\ Pоссия.E-mail: alnagov@gmail.com
}

РЕЗЮМЕ: Проартикуляты (Proarticulata), самые крупные подвижные животные позднего докембрия, обитали на мелководье нормально-соленых морских водоемов 
Балтики (Восточной и Северной Европы) и Восточной Гондваны (Австралии) в конце эдиакарского периода. Они представляли существенную часть сообщества бентосных макроорганизмов, населявших поля микробных матов, и, по крайней мере, некоторые из них питались верхним слоем мата, поглощая пищу брюшной стороной тела. Отпечатки, относимые к проартикулятам, образованы суббилатеральными объектами, расчлененными в поперечном направлении на два ряда «полусегментов» (изомеров). Установлено, что эти объекты представляли не все тело проартикуляты, а только его часть, относительно устойчивую к процессам разложения. Это разделенное на поперечные элементы мешкоподобное образование обнимало спинную и брюшную сторону тела, но не распространялось в более глубокие его части. Оно было плотным и, вероятно, несло функцию опоры. Поверх расчлененного образования располагался покровный слой, который на спинной стороне тела создавал сплошной щит, не показывавший никаких признаков сегментации. Внешняя поверхность спинной стороны проартикулят нескольких родов была покрыта многочисленными равномерно рассеянными бугорками. У одного вида покровы на заднем конце тела формировали пару длинных нитевидных выростов. Судя по следам питания, вентральная сторона организма снаружи была расчленена аналогично опорному образованию. Покровы вентральной стороны, вероятно, несли реснички, бороздки от движения которых сохраняются на следах. Покровные слои и расчлененное образование интерпретируются как эпидермальная ткань и подстилающий ее базальный матрикс. Тканевая организация в сочетании с передне-задней и дорсо-вентральной полярностью тела проартикулят позволяют относить их к Eumetazoа и Bilateria.

Как цитировать эту статью: Ivantsov Yu.A., Zakrevskaya M.A., Nagovitsyn A.L. 2019. Morphology of integuments of the Precambrian animals, Proarticulata // Invert.Zool. Vol.16. No.1. P. 19-26. doi: 10.15298/invertzool. 16.1.03

КЛЮЧЕВЫЕ СЛОВА: Dickinsonia, Yorgia, Proarticulata, Bilateria, Eumetazoa, поздний докембрий, эдиакарий.

\section{Introduction}

The Proarticulata (Fedonkin, 1985) is a large group of Precambrian macroorganisms with a transversely divided body, including such wellknown genera as Dickinsonia and Yorgia. According to M.A. Fedonkin's opinion, joined by the authors of this article, this group represents a peculiar extinct phylum of the Metazoa. Proarticulates inhabited shallow marine basins of normal salinity of Baltica (nowadays eastern and northern Europe) and East Gondwana (Australia) in the Late Ediacaran (c. 550-560 million years ago). These were the largest benthic mobile animals of the Late Precambrian; the body length of some of their representatives was dozens of centimeters, and in some cases (Dickinsonia rex) it was up to a meter or more (Jen- kins, 1996). Proarticulates represented a substantial part of benthic palaeocommunities of macroorganisms inhabiting shallow-water microbial mats (Droser et al., 2006; Zakrevskaya, 2014; Coutts et al., 2016; Evans et al., 2018). The upper lamina of such a mat served as their food source, as it was observed on several fossil species. The animals absorbed nutrients by the ventral side of the body (Ivantsov, Malakhovskaya, 2002; Gehling et al., 2005), accumulating food particles into elongated, slit-like open cavities (Ivantsov, 2008, 2013).

All the data on proarticulates were obtained from the study of their fossil remains, preserved on the bedding planes of sedimentary rocks as low-relief body impressions and imprints of feeding traces. Such fossils were found in the burials of the Flinders-Belomorian-style pres- 
ervation, specific to the Late Precambrian. These burials were formed during clastic material deposition by storms or turbidites and further redeposition of these sediments on a seabed covering its inhabitants (Narbonne, 2005; Ivantsov, Zakrevskaya, 2018). Moulds attributed to proarticulates were formed by sub-bilateral organisms, entirely or partly transversely divided within two rows of half-segments (isomers). The isomers were located on both sides along the main axis of the body in accordance with the glide plan of symmetry.

According to a grade of the body segmentation, the Proarticulata Phylum is subdivided into three classes: Vendiamorpha Fedonkin, 1985, Dipleurozoa Harrington et Moore, 1955, and Cephalozoa Ivantsov, 2004. In the body of the Vendiamorpha, isomers only are observed. A nonsegmented lobe is observed in the Dipleurozoa; it has triangular or rhombic outlines in young specimens and becomes narrow and lanceolate in mature individuals. In the Cephalozoa, a nonsegmented lobe has a crescent or horseshoe appearance and is preserved in this shape through the entire ontogeny of these animals. In a number of juveniles and in several species of the Cephalozoa, known only by small specimens, a nonsegmented lobe entirely embraces an isomeric area inside a fossil (Figs 2.6, 3). Feeding traces help to determine an anteroposterior orientation of proarticulate bodies and reveal that the nonsegmented lobe was located at the anterior end in the direction of the animal's movement (Ivantsov, 2011, 2013; Gehling et al., 2005, 2014).

Proarticulate individuals developed by addition of new isomers and a subsequent increase in their linear dimensions (Runnegar, 1982). A formation of the isomers occurred terminally at the posterior end of the body. This suggestion is confirmed by the presence of specimens being damaged during their lifespan with an injured and then regenerated growth zone (Fig. 1.5, 1.6). Although this process cannot be observed directly, the fossil material shows that in some cases the posterior end is bifurcated and an additional series of isomers appeared there which is indicative for a terminal location of the growth zone (Ivantsov et al., 2018a, b).
The transverse elements of the Proarticulata and some other Ediacarian organisms had stiff walls imparting the fossils a "quilting" appearance according to A. Seilacher (Seilacher, 1992). It is believed that the whole animal was isomeric, or it possessed an isomeric special stiff cover (Seilacher, 1989; Dzik, Ivantsov, 2002; Fedonkin, 2002). New data allow us to clarify this problem.

\section{Material}

The material for this study was a series of unique specimens of proarticulate fossils collected in the southeastern White Sea area (Russia, Arkhangelsk region) and stored in the Laboratory of Precambrian Organisms of PIN RAS (collection No. 3993 and 4716).

\section{Results and discussion}

Our observations show that the majority of known moulds of the Proarticulata (Figs 1.1, $1.2,1.5,1.6,2.1,2.3)$ did not represent remains of complete bodies of an organism, but only a part, that was relatively resistant to decomposition and further diagenetic changes. Despite all these alternations, organic matter of such a fossil is able to be preserved to the present allowing biochemical studies (Bobrovskiy et al., 2018). The body isomers are expressed in the organic matter in the form of alternating stripes of a different dark colour hue. On the most representative specimens, we observe imprints of the upper side of a segmented structure with a more or less uniform arrangement of the isomers (Fig. 1.1a). If the organic matter itself is preserved, a shift of the striped pattern in relation to the transverse elements of the imprint can be seen at different, sometimes quite large angles (Fig. 1.1b). The same shift is also observed in the position of the food-accumulating cavities (Ivantsov, 2013), which are bent towards the ventral side of the body. The pattern on the organic matter distribution also seems to reflect the segmentation of the lower side. This means that a mechanical connection between the upper and lower parts of the divided structure was 

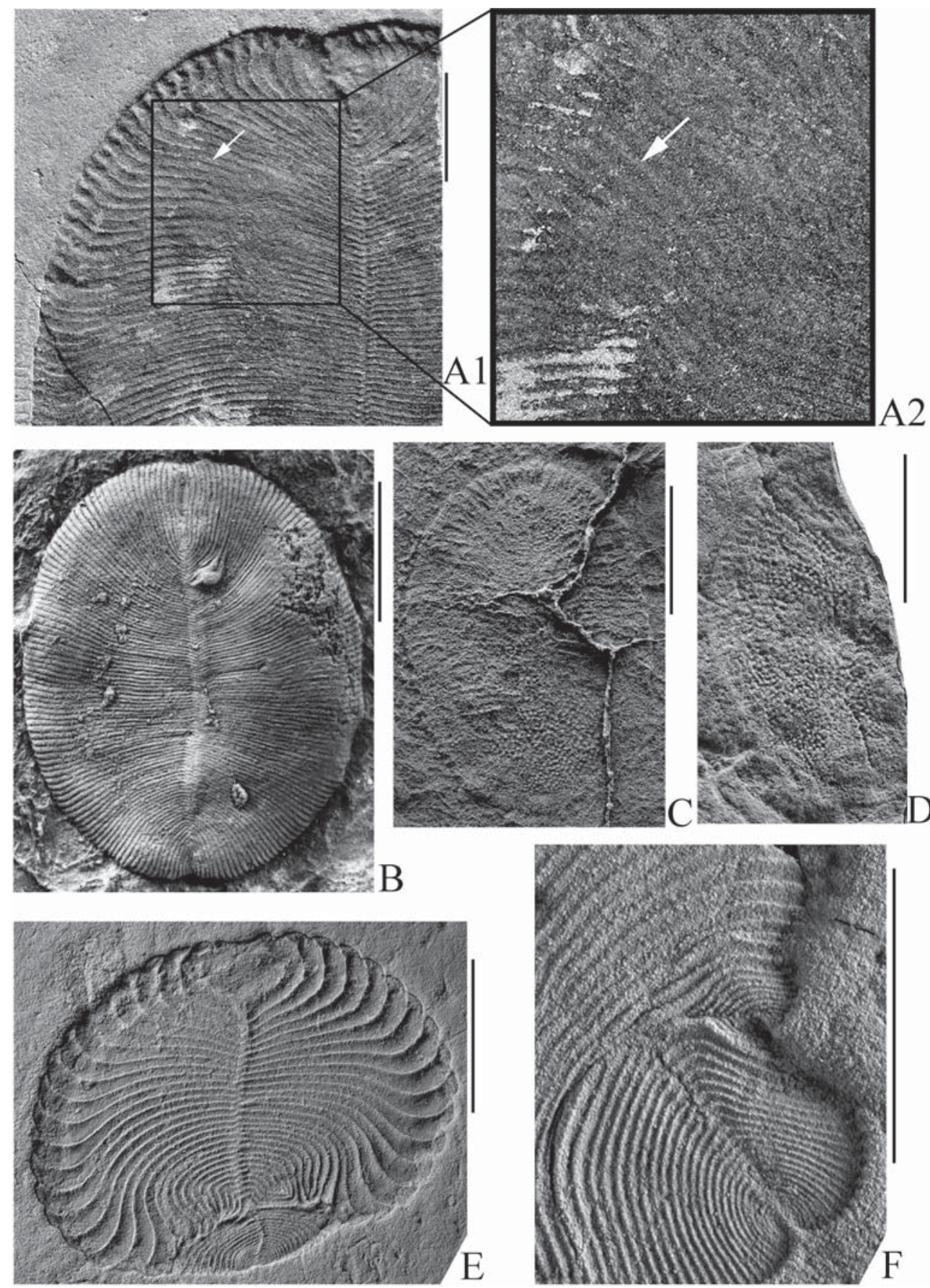

Fig. 1. Proarticulata of the southeastern White Sea area (A, E, F - Dickinsonia cf. menneri, natural moulds, B-D - Dickinsonia cf. tenuis, latex casts of moulds; length of the scale segment $-1 \mathrm{~cm})$ : A - specimen PIN No. 4716/5147, imprint of the dissected structure with preserved organic matter (A1 — relief of the dorsal side, photo with oblique lighting, A2 - fragment of organic matter with larger magnification and frontal lighting, the group of the isomers of the ventral side are marked with an arrow); B - specimen PIN 
rather weak. It was easily disrupted during burial compression within the sediment leading to a shift of the upper and inner parts relative to each other on the resulting imprint. Thus, the structure, divided into transverse elements, had an appearance of a sack developed on the dorsal and ventral sides of a proarticulate body, but probably did not spread to its inner parts. The common preservation of such fossils, including organic matter, indicates that the material forming the divided structure was relatively stiff and biochemically stable. It can be suggested that this structure served as a resilient support in the body of the Proarticulata.

Judging by rare specimens of a peculiar preservation, another cover layer or integument is inferred over the divided structure. On the dorsal side of the body, it creates a continuous shield that lacks signs of segmentation (Fig. 2.2). The outer surface of the dorsal side of several genera (Dickinsonia, Yorgia, Archaeaspinus, Lossinia, Onega) is covered with numerous evenly distributed tubercles (Figs 1.3, 1.4, 2.2, 2.5, 2.6, 2.7). Onega stepanovi, known by the small specimens not exceeding a few millimeters in length, sometimes has a pair of long filamentous outgrowths at the posterior end of the body (Fig. 3). The outgrowths are approached spatially the last two isomers; however, they do not affect neither the size nor the shape of the isomers. Therefore, it can be assumed that the filamentous outgrowths of One$g a$ were formed by cover tissue.

Judging by feeding traces, the ventral side of the organism was subdivided externally alike the supporting structure. The boundaries between the transverse elements (crests on the original trace and furrows on its mould, marking the location of the slit-like apertures of the foodcollecting grooves) are not always clearly expressed here; they can be vanished on the lateral margins of the body (Fig. 2.4). Based on the details of the trace fossil morphology, it is suggested that the traces were created mechanically, most likely by a ciliary sweeping. In Yorgia waggoneri, which left the most pronounced traces, these hypothetical cilia appear to have been arranged in bunches, the furrows from the movement of which are preserved on trace fossils (Ivantsov, 2008, 2011).

Thus, the integuments of the dorsal and ventral sides of the Proarticulata were different. The dorsal cover was continuous and bore relatively large tubercles and sometimes long outgrowths. The ventral one was dissected by grooves and had a smooth surface, probably bearing cilia (Fig. 4). The integument and the segmented structure of proarticulates can be interpreted as an epidermal tissue and a basal matrix underlying it respectively, which is in character with the eumetazoan level of organization.

An inner part of proarticulate body occurred deeper under the layer of the basal matrix and exceeded the volume of the integument. In part this room was occupied by food-accumulating/ digestive cavities having a different pattern in various genera. Other data on the structure of the inner part are rather scarce. For instance, thin branching canals (Fig. 1.3), which were

No. 3993/5172, upper surface of the dissected structure; C, D - specimen PIN No. 3993/8500 and 3993/ 6414 , respectively, nonsegmented structure with fragments of the tuberculate dorsal cover; E, F - dissected structure with signs of regeneration of the posterior end (E - specimen PIN No. 4716/5187, normal recovering of the growth zone; F - specimen PIN No. 4716/5146, splitting of the growth zone in two). Рис. 1. Проартикуляты Юго-Восточного Беломорья (А, Е, F — Dickinsonia cf. menneri, естественные отпечатки, B-D - Dickinsonia cf. tenuis, латексные слепки с естественных отпечатков; длина масштабного отрезка - 1 см): А — экз. ПИН № 4716/5147, отпечаток расчлененного образования с сохранившимся органическим веществом (A1 - рельеф спинной стороны, фото при косом освещении, А2 - фрагмент органического вещества при большем увеличении и фронтальном освещении, стрелка указывает на группу изомеров вентральной стороны); В — экз. ПИН № 3993/5172, верхняя поверхность расчлененного образования; C, D - экз. ПИН № 3993/8500 и 3993/6414, соответственно, расчлененное образование с фрагментами бугорчатого дорзального покрова; Е, F расчлененное образование со следами регенерации заднего конца (Е - экз. ПИН № 4716/5187, нормальное восстановление зоны роста; F — экз. ПИН № 4716/5146, расщепление зоны роста надвое). 
A.Yu. Ivantsov et al.
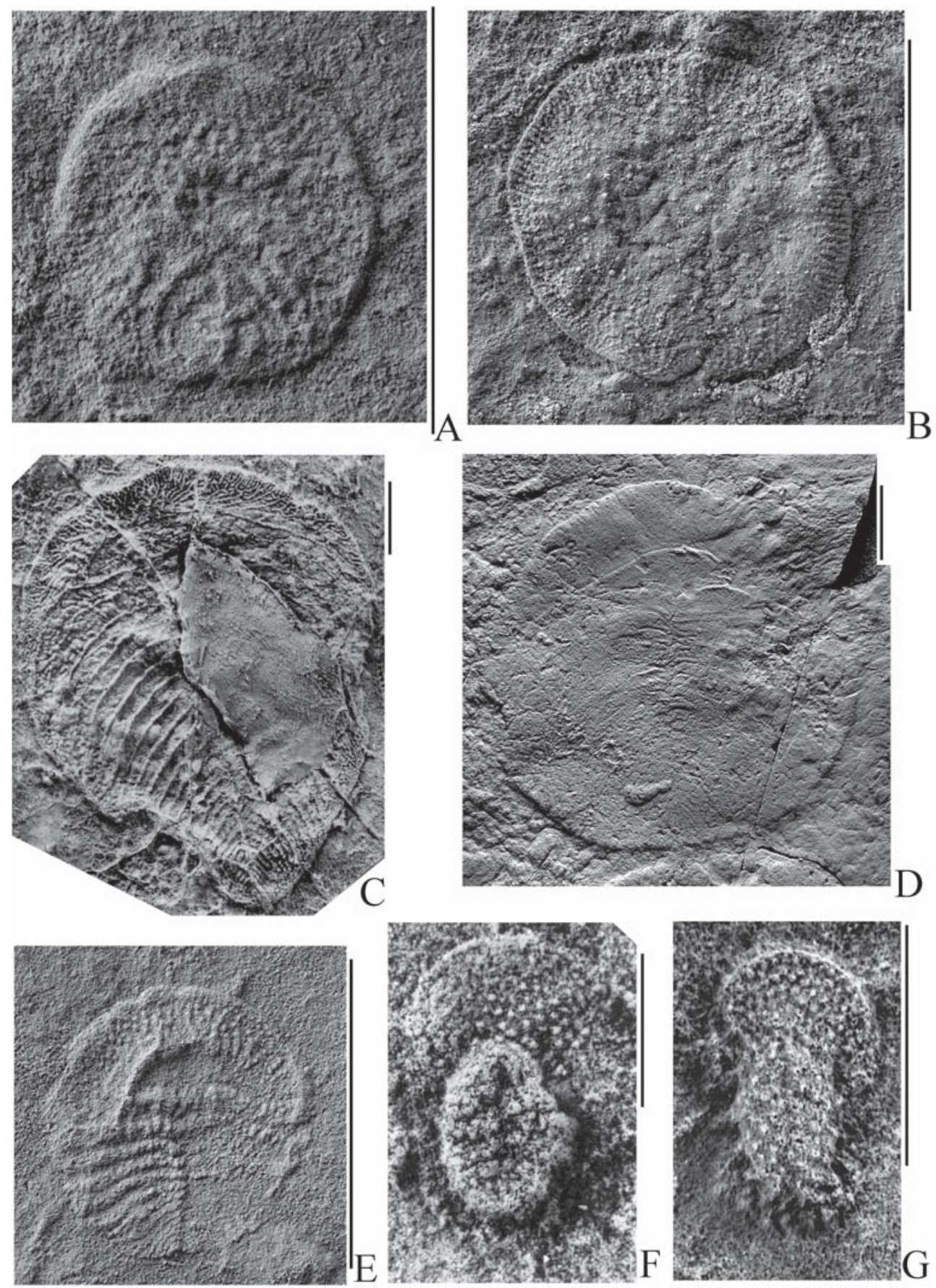

Fig. 2. Proarticulata of the southeastern White Sea area (A-C, E-G - latex casts of moulds, D - natural imprint of the feeding trace; length of the scale segment $-1 \mathrm{~cm}(\mathrm{~A}-\mathrm{E}), 0.3 \mathrm{~cm}(\mathrm{~F}, \mathrm{G}))$ : A-D - Yorgia waggoneri (A, C - upper side of the dissected structure, specimen PIN, No. 3993/5135 and 3993/9820, respectively; B - dorsal side of the body, specimen PIN no. 3993/5501, D — ventral side, specimen PIN No. 3993/5149); E - Archaeaspinus fedonkini specimen PIN No. 3993/5633; F — Onega stepanovi, specimen PIN No. 3993/6795; G — Lossinia lissetskii, specimen PIN, 3993/9819. 

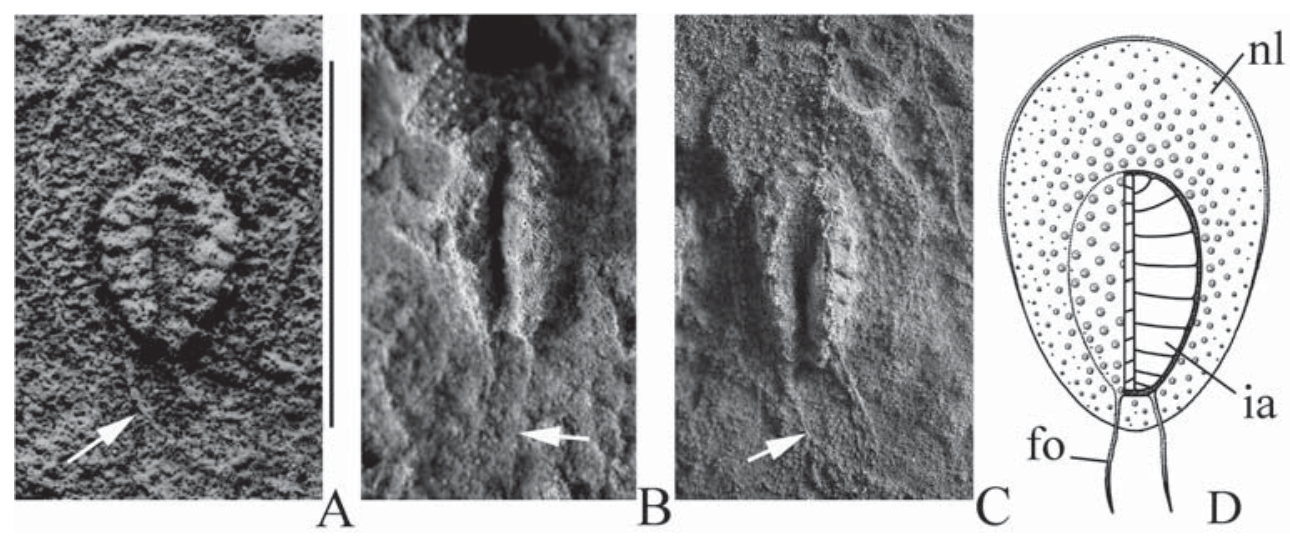

Fig. 3. Onega stepanovi: A-C — latex casts of moulds (A - specimen PIN No. 3992/5005, B, C — samples from a private collection; the arrow marks the filamentous outgrowths; length of the scale segment -0.5 $\mathrm{cm}), \mathrm{D}$ - schematic reconstruction. Abbreviations: $\mathrm{nl}$ - nonsegmented lobe, ia - isomeric area, fo filamentous outgrowth.

Рис. 3. Onega stepanovi: А-C — латексные слепки с естественных отпечатков (А - экз. ПИН № 3992/ 5005, В, C - образцы из частной коллекции; стрелка указывает на нитевидные выросты; длина масштабного отрезка - 0,5 см), D - схематическая реконструкция. Обозначения: $\mathrm{nl}$ - нерасчлененная лопасть, іа — изомерная область, fo - нитевидный вырост.

interpreted as probable ducts of the secretory glands (Ivantsov, 2008), were distinguished in the head lobe of a number of the Cephalozoa. A structure, resembling the digestive-distributive system of some turbellarians, was detected in one of the species of the Dipleurozoa (Ivantsov, 2008; Dzik, Ivantsov, 2002). Our imperfect knowledge of the internal anatomy of the Proarticulata is explained by the masking effect of external integuments. However, the accumulated data as a whole indicate a relatively high level of organization of these animals. The anteroposterior and dorsoventral polarity of the body in combination with signs of an incipient cephalization (expressed in a morphological distinction of the anterior section and a directional movement of these animals in a search for food) suggest that the Precambrian Proarticulata already achieved a bilaterian grade of development, although they had a specific type of symmetry atypical for the Bilateria.

\section{Acknowledgments}

The photographs were made by S.V. Bagirov (PIN RAS). The field work and the preparation of the fossil material were carried out with the support of the Russian Foundation for Basic Research, Grant No. 17-05-02212-a. The studies are supported by the grant for the fundamental research on the topic of the state assignment of PIN RAS, "The emergence of life, the formation of the biosphere, and the development of ancient biotas".

\section{References}

Bobrovskiy I., Hope J.M., Ivantsov A., Nettersheim B.J., Hallman C., Brocks J.J. 2018. Ancient steroids establish the Ediacaran fossil Dickinsonia as one of the earliest animals // Science. Vol.361. P.1246-1249.

Coutts F.J., Gehling J.G., Garcia-Bellido D.C. 2016. How diverse were early animal communities? An example from Ediacara Conservation Park, Flinders Ranges, South Australia // Alcheringa. Vol.40. P.407-421.

Рис. 2. Проартикуляты Юго-Восточного Беломорья (A-C, E-G - латексные слепки с естественных отпечатков, D - естественный слепок следа питания; длина масштабного отрезка для A-E - 1 см, для F, G - 0,3 см): A-D - Yorgia waggoneri (A, C - верхняя сторона расчлененного образования, экз. ПИН № 3993/5135 и 3993/9820 соответственно; В — дорзальная сторона тела, экз. ПИН № 3993/5501, D — вентральная сторона, экз. ПИН № 3993/5149); Е_-Archaeaspinus fedonkini, экз. ПИН № 3993/5633; F — Onega stepanovi, экз. ПИН № 3993/6795; G — Lossinia lissetskii, экз. ПИН № 3993/9819. 


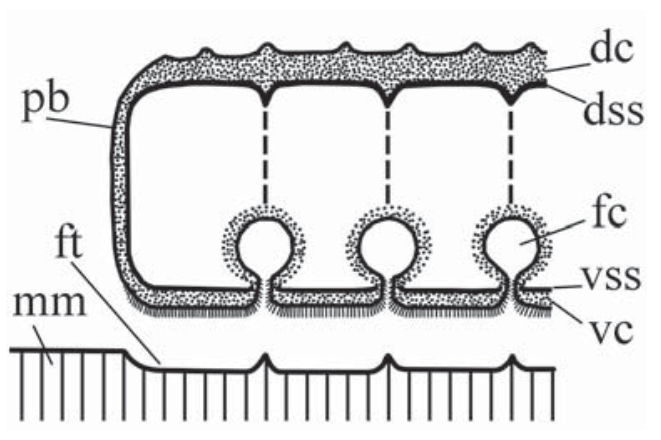

Fig. 4. Reconstruction of the integument structure of the Proarticulata judging by the analysis of body impressions, imprints of internal structures, and feeding trace fossils. Abbreviations: $\mathrm{pb}$ - proarticulate body, $\mathrm{ft}$ - feeding trace, $\mathrm{mm}$ - microbial mat, dc - dorsal cover, vc - ventral cover, fc food-accumulating cavity, dss - dorsal part of the supporting structure, vss - ventral part of the supporting structure.

Рис. 4. Реконструкция строения покровов проартикулят на основании анализа отпечатков тел, слепков внутренних структур и следов питания. Обозначения: $\mathrm{pb}$ - тело проартикуляты, $\mathrm{ft}-$ след питания, $\mathrm{mm}$ - микробный мат, $\mathrm{dc}$ - дорзальный покров, vc - вентральный покров, fc пищесборный карман, dss - дорзальная часть опорного образования, vss - вентральная часть опорного образования.

Droser M.L., Gehling J.G., Jensen S.R. 2006. Assemblage palaeoecology of the Ediacara biota: The unabridged edition // Palaeogeography, Palaeoclimatology, Palaeoecology. Vol.232. P.131-147.

Dzik J., Ivantsov A.Yu. 2002. Internal anatomy of a new Precambrian dickinsoniid dipleurozoan from northern Russia // N. Jb. Geol. Palaont. Mh. Stuttgart. Vol.7. P.385-396.

Evans S.D., Dzaugis P.W., Droser M.L., Gehling J.G. 2018. You can get anything you want from Alice's Restaurant Bed: exceptional preservation and an unusual fossil assemblage from a newly excavated bed (Ediacara Member, Nilpena, South Australia) // Australian Journal of Earth Sciences. P.1-11.

Fedonkin M.A. 1985. [Systematic description of the Vendian Metazoa] // Vendskaya sistema. Istoriko-geologicheskoye i paleontologicheskoye obosnovaniye. T.1. Paleontologiya. M.: Nauka. P.70-106 [in Russian].

Fedonkin M.A. 2002. Andiva ivantsovi gen. et sp. nov. and related carapace-bearing Ediacaran fossils from the Vendian of the Winter Coast, White Sea, Russia // Ital. J. Zool. Vol.69. P.175-181.

Gehling J.G., Droser M.L., Jensen S.R., Runnegar B.N. 2005. Ediacara organisms: relating form to function // Evolving form and function: fossils and development.
New Haven: Yale Univ. Press. P.43-66.

Gehling J.G., Runnegar B.N., Droser M.L. 2014. Scratch Traces of Large Ediacara Bilaterian Animals // Journal of Paleontology. Vol.88. No.2. P.284-298.

Ivantsov A.Yu. 2008. [Proarticulata - a phylum of multicellular animals that became extinct in the Precambrian] // Yu.V. Mamkaev (ed.). Evolyutsionnaya morfologiya zhivotnykh. K stoletiyu so dnya rozhdeniya akad. A.V. Ivanova. Ch.I. Tr. S.-Peterb. o-va estestvoispytateley. Ser.1. T.97. Sankt-Peterburg: Izd. SPbGU. P.32-42 [in Russian].

Ivantsov A.Yu. 2011. Feeding Traces of Proarticulata - the Vendian Metazoa // Paleontological Journal. Vol.45. No.3. P.237-248.

Ivantsov A.Yu. 2013. Trace Fossils of Precambrian Metazoans "Vendobionta" and "Mollusks" // Stratigraphy and Geological Correlation. Vol.21. No.3. P.252-264.

Ivantsov A.Yu., Malakhovskaya Ya.E. 2002. Giant traces of Vendian animals // Doklady Earth Sciences. Vol.385A. No.6. P.618-622.

Ivantsov A.Yu., Zakrevskaya M.A. 2018. [The phenomenon of the exceptional preservation of Late Precambrian macrofossils] // Trudy Paleontologicheskogo obshchestva. T.I. Moskva: PIN RAN. P.46-53 [in Russian].

Ivantsov A.Yu., Zakrevskaya M.A., Nagovitsyn A.L. 2018a. [Intravital damages of the body of and morphogenesis of Dickinsonia (Late Precambrian macroorganisms)] // Fundamental'naya i prikladnaya paleontologiya. Materialy LXIV sessii Paleont. obshchestva pri RAN. Sankt-Peterburg. P.47-49 [in Russian].

Ivantsov A.Yu., Zakrevskaya M.A., Nagovitsyn A.L. 2018b. The first evidence of disability in the "Garden of Ediacara" // The fossil week. $5^{\text {th }}$ International Palaeontological Congress. Abstract book. P.294.

Jenkins R.J.F. 1996. Aspects of the geological setting and palaeobiology of the Ediacara assemblage//M. Davies, C.R. Twidale, M.J. Tyler (eds.). Natural History of the Flinders Ranges. Royal Society of South Australia. Vol.7. P.33-45.

Narbonne G.M. 2005. The Ediacara Biota: Neoproterozoic origin of Animals and their ecosystems // Annual Review of Earth and Planetary Science. Vol.33. P.421442.

Runnegar B. 1982. Oxygen requirements, biology and phylogenetic significance of the late Precambrian worm Dickinsonia, and the evolution of the burrowing habit // Alcheringa. Vol.6. P.223-239.

Seilacher A. 1989. Vendozoa: Organismic construction in the Proterozoic biosphere // Lethaia. Vol. 22. No.3. P.229-239.

Seilacher A. 1992. Vendobionta and Psammocorallia: lost constructions of Precambrian evolution // Journal of the Geol. Society. London. Vol.149. No.4. P.607-613.

Zakrevskaya M.A. 2014. Paleoecological reconstruction of the Ediacaran benthic macroscopic communities of the White Sea (Russia) // Palaeogeography, Palaeoclimatology, Palaeoecology. Vol.410. P.27-38.

Responsible editor A.Yu. Zhuravlev 